\title{
Dos paradigmas contrapuestos en la evaluación educativa, dos formas diferentes de concebir al alumno
}

\author{
Villalba, Andrea
}

\section{Resumen}

En este artículo se abordan dos formas vigentes de entender la evaluación educativa. Se mencionan los rasgos sobresalientes de cada una de ellas y se reflexiona sobre el rol del docente y su concepción del alumno según se adhiera a una evaluación de carácter cuantitativo o cualitativo.

Palabras clave: evaluación cualitativa, evaluación cuantitativa.

\section{Sumary}

Two paradigms opposing in educational evaluation, two different ways of conceiving the student

This article addresses two extreme and understand current educational assessment. Mentioned the salient features of each and reflects on the role of the teacher and student as his conception of adhering to an evaluation of quantitative or qualitative.

Keywords: qualitative evaluation, quantitative evaluation. 